\title{
IS ARTIFICIAL REGENERATION NECESSARY IN NEWFOUNDLAND? ${ }^{1}$
}

\author{
BY FINN FROST ${ }^{2}$
}

Mr. Frost has the degree of Skogbrukskandidat (equivalent to Master of Forestry) from the Agricultural University of Norway. One year in the U.S. Forest Service with a scholarship from the American-Scandinavian Foundation Lecturer in Forest Botany. Two years with the Forestry Commission in Scotland. Five years Forestry Consultant, Norwegian Department of Agriculture. Six years Woods Manager ("Skogforvalter") in Norwegian Crown Forests. Four years Forester to the Newfoundland Department of Mines and Resources, also Lecturer in forestry subjects at Memorial University of Newfoundland. An officer in the Norwegian Army during the war. Member of C.I.F., the Royal Scottish Forestry Society, the Society of Foresters of Great Britain, and the Society of Norwegian Foresters.

The forest industries in Newfoundland are very young. A short period of years before the turn of the century saw a flourishing but unstable sawmill industry based on old white pine as the main raw material. The white pine is a dying species in Newfoundland-doomed by the blister rust and other diseases, and by insects; a species which today is for a large part represented by overmature trees that look like monuments of a bygone forest era. There is very little white pine reproduction to be found, and with the forests full of Ribes plants, the poor stately tree has hardly any chance of survival at all. Some fir and spruce were used, but only the larger trees were felled - a cutting system which had little or no influence on the reproduction.

The picture changed totally with the establishment of the paper industry - Grand Falls mill starting about 1907 and the Corner Brook Mill 20 years later. This was truly a happy turn of the wheel of history as Newfoundland is predominantly a pulpwood country, with dense stands of fir and spruce which are ideal for the production of high quality pulp and paper.

The forest industries are of vital importance to the well being of the Province. According to the Report of the Newfoundland Royal Commission on Forestry, the income derived from the forest industries in 1952 was $31.6 \%$ of the total income - against $12.3 \%$ for mining and $9.8 \%$ for the fishing industries. The tremendous growth of the forest industries has taken place within the very short time of half a century with the fastest growth having taken place in the most recent years.

Is there any reason to believe that this growth has come to a total halt now? The Canadian Pulp and Paper Association has presented a most interesting and heartening paper to the Royal Commission on Canada's Economic Prospects - the Gordon Commission. The Association predicts that the demand on the Canadian forests for pulpwood will increase by $110 \%$ during

\footnotetext{
${ }^{1}$ A paper presented at the annual mecting of the Newfoundland Section of the C.I.F. at Grand Falls, December 1957.

a Forester, Department of Mines and Resources, St. John's, Newfoundland.
} 


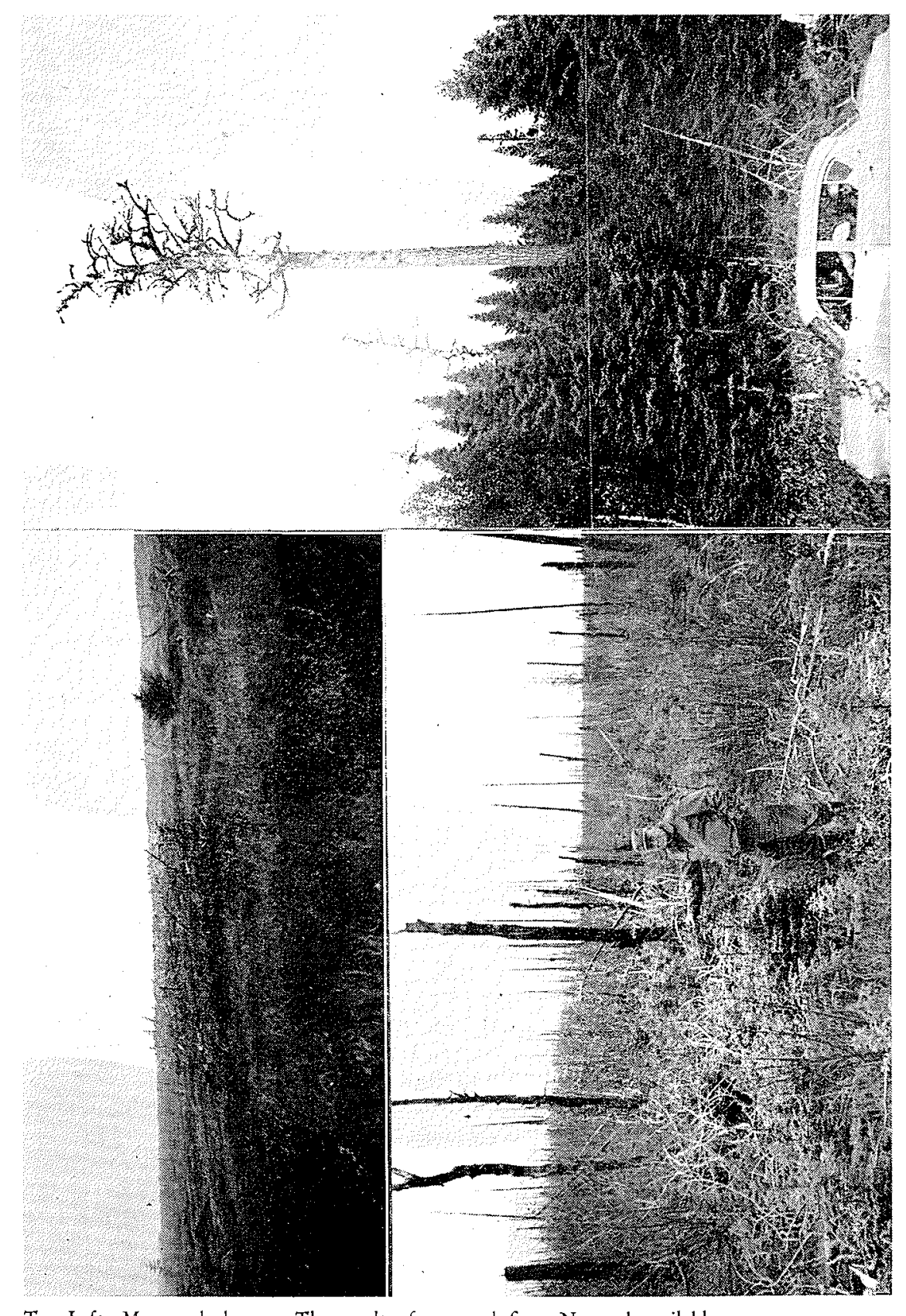

Top Left: Man-made barren. The result of repeated fires. No seed available.

Bottom Left: The 1943 Gambo fire. Excellent reproduction of black spruce, 10 years after fire. The burned timber, which had a lot of secd, has been cut over a period of 4 to 5 years. Right: White pine over sprucc and fir. A monument of a bygone era. 
the 25 years - from 1955 to 1980 . Now while most of the world is suffering from a recession, it is easy enough for some people - the pessimists - to claim that such a growth is impossible. However, the growth during the past 25 years was even larger - about $150 \%$.

The main question, of course, is how the standard of living in the world as a whole will develop. But provided the world goes forward, all the Canadian forest industries are bound to benefit from this progress since most countries have to import their paper needs. It is true that other countries with a warmer climate may develop a greater pulp and paper production based on plantations of pine species such as Monterey pine (Pinus radiala), or on fast growing hardwoods such as eucalypts. But these possibilities should not restrict silvicultural activities in Newfoundland.

The consumption of paper is a good indicator of a country's standard of living. Annually the U.S.A. uses over 400 lbs. per head, Canada 250-300, Sweden less than 200, and the far east countries like India and China only 2 to 3 lbs. per head. There is a world-wide cry today for higher educational standards which means more paper will be needed.

Now let us go back to the forests of Newfoundland. Are we in a position to follow the pattern predicted for the whole of Canada? We have the men who know the art of bringing the logs to the mills and turning the logs into high grade finished products. But can our forests stand a doubling of the annual cut by 1980 ?

The Forestry Commission estimated a few years ago that the forests of the Island of Newfoundland should be able to stand an increased annual cut of 200,000 cords. But this represents only about $20 \%$ of the total cut of today - against the $110 \%$ predicted for all Canada. Further developments might come to a standstill in a few years time if history follows the prediction of the Canadian Pulp and Paper Association.

We could increase the annual cut by $110 \%$ if we could bring the untapped riches of Labrador into production. Here we have 75 million cords of excellent pulpwood, virtually a vast ocean of forests untouched by human hands, the last great virgin timber land on the shores of the Atlantic Ocean. There can be no doubt about it-it is only a matter of time before the stillness is broken by hissing power saws and clattering tractors.

But Labrador lies far away over the seas, and presents many problems which must be solved before it can help to feed the paper mills of the Province to any appreciable extent. It is more natural and it is probably cheaper to increase the yield of the forest land of the island, even if it may cost ten dollars or more per acre to obtain such an increase.

Let us first have a look at the burned-over areas. It is a fact that most of our fine stands of black spruce have come up after fire - thanks to the ingenious trick of mother nature in storing cones and live seeds in the tree tops for years, allowing the seed to fall to the ground after a fire has swept the forest. The fact that there are no squirrels in Newfoundland to feed on the cones is undoubtedly another important factor for the successful regeneration of burned black spruce stands. A good reproduction of black spruce is always secured after a fire except in cases where there is no supply of seed available. Failure of reproduction may occur when fire has swept through young stands 
where the trees are too young to produce cones, or where fire has run over or through the clearfelled areas where no conebearing trees are left. Repeated burns may even develop into patches of real desert as we can see on the Brigus Barrens, where all the organic matter has been burned off on some of the drier ridges.

Let us have a closer look at the regeneration after some of the fires. The Halls Bay fire of 1951 has resulted in an excellent reproduction of black spruce, thanks to the presence of sufficient seed trees. The same type of fine black spruce reproduction can be seen today after the fire of 1947 south of Gander Lake. The province experienced some large fires at the turn of the century when a large part of the forests of central Newfoundland was burned. One of the largest fires occurred in 1897 , followed by a 900 -sq.-mi. fire in 1903. Most of these burned-over areas have become excellent stands of black spruce, which already give pulpwood to the paper mills.

But the picture is not so bright after every fire. Reproduction after a number of fires has been studied by W. A. Dickson of the Federal Forestry Branch and reported in a very interesting paper in 1955.

He found that, after the North Pond Gambo fire of 1941, about twothirds of the burned area was not successfully restocked.

Of the Triton Brook 1943 Burn the regeneration is far from satisfactory. I quote from the report: " $44 \%$ is classed as hopeless from a regeneration standpoint".

At the Terra Nova 1947 Burn the percentage of successful regeneration is not stated, but the report says: "Only under a very few uncut patches of burned black spruce was satisfactory regeneration encountered".

Of the Upper Gambo Pond 1950 burn: "Here $49 \%$ of the area had an almost total failure to regeneration. On the better sites about $30 \%$ regeneration success to black spruce was found."

At the Cormack 1949 Burn only $18 \%$ of the area has satisfactory reproduction - where there were enough fire killed black spruce seed trees.

Results of reproduction studies reported by Candy from studies carried out by Robertson 1947-49 also give a high percentage of unsatisfactory reproduction after fire. For 3,550 quadrats in central Newfoundland he found that only $41 \%$ to $47 \%$ were stocked.

The next question is: how many acres are burned? During the years of 1945-56 a total of 569,338 acres of forest land burned. Deducting for "barren, brush and scrub, grass and marsh" the remaining burned-over area - which should be productive forest land - is 255,719 acres.

It is deplorable that we do not know how much of this huge area has been restocked with commercial species of satisfactory density. Using the above mentioned studies of the Federal Forestry Branch and the findings of Mr. Robertson as a guide for guessing, I would not be surprised if a closer survey found the area unsatisfactorily restocked after the fires of 1946-57 to be of the order of $\mathbf{1 5 0 , 0 0 0}$ acres which is lost to satisfactory timber production for a very long period of time. And this is only the loss through fires which have occurred during a ten years' period. 
Such a loss of productive forest land may not be so serious as long as we have a surplus of timber and as long as we are only interested in the near future. But the day is approaching rapidly when further development of our forest industries cannnot take place simply because there will not be enough timber in the island.

A large part of the above mentioned area should be brought into production by sowing or planting. Planting is, of course, the safest method. But thanks to our Atlantic climate which gives us a rainy day every so often and thanks to the absence (or small number) of seed-eating rodents and birds, we may obtain success by using the cheaper method of seedspotting.

How much would 150,000 acres of spruce be worth to the Province 60 years after reproduction had taken place? A low cordage of 15 cords per acre would give 2.25 million cords. Exported as paper the value would be (based on present day's price) of the order of $\$ 225$ million that would fall like "manna" over the entire populace, but first and foremost over the man who swings the axe and hauls the logs, to the man who produces the fibre and rolls out the paper. With luck there may even be a dollar or two left in the pot for the shareholders.

I honestly think it is time now to start something - for example collecting spruce cones and extracting seed. Recent burns should be analyzed, and sowing should be carried out wherever nature needs help. On the best soils we shall probably find that we have to plant instead of using seed directly.

It is not only burned areas that are in need of help in order to obtain new good stands of timber. It is true that most of the areas clearfelled by the companies have fine stands of young growth. But I cannot really see how the clearfelling of areas of dense 50 to 60 years old black spruce stands can result in satisfactory reproduction.

This type of forest usually develops a thick mat of feather mosses which constitutes a most difficult seed bed. The fallen tree tops may have a lot of cones, but it is a question if the cones are able to open. If some seed should fall to the ground it still has the difficult thick mat of feather mosses to cope with.

Robertson found only $55 \%$ to $59 \%$ of 5,170 sample quadrats stocked following logging in central Newfoundland.

I cannot let this opportunity pass without having a stab at the arch enemy, the balsam woolly aphid. The large areas of the West Coast forests which are infested by this insect need some drastic help. The soil is good, but with the quality and the growth of the balsam fir reduced to a minimum, the yield of the soil in the form of commercial timber will be very low except where spruce is the dominant species. Here I believe prescribed or controlled burning, possibly followed by sowing or planting of spruce is necessary - and indeed practical - in order to bring the soil back to valuable production.

We should bear in mind the advantages spruce has over fir. The spruce is much more resistant to insect attack, and it has a $20 \%$ to $30 \%$ higher yield of paper per cord. This difference in wood density has a considerable influence on the whole production picture since such a large part of the total 
cost of producing a ton of paper is based on the cord, regardless of fibre yield. All costs of pulpwood operations - cutting, hauling, driving, storing at the mill, insurance, overhead, interest on investment, and all expenses probably past the digester and the grindstone - are based on volume and not on weight.

The price of newsprint today is roughly $\$ 100$ per cord. Let us say the expenses are anchored to wood volume - to the cord - half way through to the finished product. This means that a cord of spruce costs about $\$ 10.00$ less than a cord of balsam fir. In the daily production the mills, of course, use a mixture of spruce and fir - but the advantages of the spruce are still $20 \%$ to $30 \%$ ahead of the fir.

Now what does this difference mean when using the acre as basis for calculation? It should be possible to obtain at least 20 cords of black spruce per acre in 60 years' time on good soil (a contract of 4,000 to 5,000 cords at the Sandy River had 27 cords of black spruce as average per acre, age about 55 years).

Thus 20 cords@ $\$ 10.00$ yields $\$ 200$ per acre which is the dollar advantage spruce has over fir in the present example.

Does it pay to reforest areas with spruce, areas which otherwise would come back in fir or in worthless shrub? If unemployed men are used for the job the matter of compound interest on the invested money should not be too important. However, even from a purely economic point of view such reforestation investmest should be fully justified.

Dickson suggests that seedspotting may cost about $\$ 7.00$ per acre. Let us for argument's sake use an expenditure of $\$ 10.00$ per acre, and $4 \%$ compound interest.

$$
\begin{aligned}
& \$ 10.00 @ 4 \% \text { p.a. in } 60 \text { years }=\$ 105.19 \\
& \$ 200.00 \text { minus } \$ 105.19=\$ 94.81
\end{aligned}
$$

This means that if an area after 60 years has 20 cords of man-established spruce, this will be worth $\$ 94.81$ more than a similar area of 20 cords of naturally reproduced fir.

The case for artificial regeneration is of course much stronger for land which does not reproduce satisfactorily, and for land infested by the balsam woolly aphid. Let us say we seedspot 1,000 acres of the Cormack burn or any burn which needs seedspotting. In 60 years' time the area would give timber at an export value of two million dollars, while the cost with compound interest, using the above calculation as basis, would amount to $\$ 105,190$.

There is of course another factor which weighs greatly in favor of the idea of spending money on artificial regeneration. "Cheap wood" - wood which is growing within easy reach of the mills - is getting scarcer all the time. In order to obtain enough wood it is necessary to cut in areas farther and farther afield bringing the cost per cord delivered at the mill site higher all the time as the years pass and as the amount of easily accessible wood shrinks. It should pay to bring the soil outside the door of the mill back to production instead of opening up expensive forests which lie 200 to 300 miles away.

This situation is not confined to Newfoundland. Many mills all across Canada are in the same dilemma. Some mills and some provinces have realized 
the need for, and indeed the advantages of planting and sowing and other forms of intensive forest management.

I am not now touching the problem of who is going to pay for the work. But it is a matter of concern for the companies, for the Province and for the whole of Canada. I only want to say that it is in the interest of everybody to have prosperous, healthy and vigorous forest industries.

Most countries with extensive reforestation work have gone through three general phases in their history of forest management.

Phase One: First there is a surplus of wood with management concentrating on harvesting the virgin forests. The public is very little concerned with sustained yield or reproduction and the stumpage value of timber is low.

Phase Two: The forest industries have difficulties in feeding the mills with timber and they have to go farther afield to fetch it. A few voices are heard regarding sustained yield, and some reforestation work for experimental and educational purposes is carried out. The public opinion is still passive, and it is difficult to obtain money for any kind of reforestation plans. However some countries bave voted considerable sums of money for such projects in cases where the main political object has been to combat unemployment (the "Civilian Conservation Corps" in U.S.A. and large scale work on forest drainage in Scandinavia in the unhappy thirties).

Phase Three: The forest industries have developed timber needs which cannot be met through normal cutting. The mills and the countries concerned lose vast sums of money in years when the world markets are clamoring for forest products.

It is when Phase Three is reached and has prevailed for some years that the need for sowing and planting and other forms of proper forest management really reaches home to the minds of the public. This is the story of Switzerland, Germany, Denmark, Finland, Sweden, Norway, Australia, New Zealand, and many other countries, also of some states in the United States.

Is the pattern of history in forest management in Newfoundland going to follow in the steps of the older countries, or is it possible to learn from other people's errors and through education, enthusiasm and courage to speed up the process, and effectuate some modest but well planned projects in reforestation? If we follow the usual pattern of non-action, there is bound to be a long period of years when the mills have to use expensive wood, and when further development of our forest industries will be at a standstill because of lack of timber.

\section{REFERENCES}

W. A. DICKSON and D. E. NICKERSON. 1955. Forest reproduction in Newfoundland. Can., Dept. Northern Affairs and National Resources, Forestry Branch. Unpub. M.S. St. John's, Nfld.

Newfoundland Forest Protection Association Annual Reports. 